\title{
Edom in the Book of Numbers: Some Literary Reflections
}

\author{
Bradford A. Anderson \\ Mater Dei Institute of Education, Dublin City University, Ireland
}

\begin{abstract}
The two references to Edom in Numbers (20,14-21 and 24,18-19) are often assumed to be unrelated and as such are usually dealt with in isolation from one another. This article suggests continuity may be found in the fact that, taken together, these references offer a depiction that has much in common with the representation of Edom put forward in the prophetic literature. These similarities between Numbers and the prophets can be seen in terms of the negative disposition towards Edom as well as in the occurrence of specific key words and verbal resonances. Moreover, the continuity in the depiction of Edom in Numbers and the prophets suggests a corresponding discontinuity with the representation of these themes in other traditions, notably Genesis and Deuteronomy.
\end{abstract}

Man geht oft davon aus, dass die zwei Erwähnungen von Edom in 4. Mose (20,14-21 and 24,18-19) keinen Bezug miteinander haben und werden daher gewöhnlich unabhängig voneinander behandelt. Dieser Artikel behauptet, dass Kontinuität erkennbar ist, denn wenn man beide Erwähnungen zusammen behandelt, dann zeigen sie ein Bild, dass sehr viel mit der Darstellung von Edom in der prophetischen Literatur gemeinsam hat. Diese Ähnlichkeiten zwischen 4. Mose und den Propheten können sowohl in der negativen Haltung gegenüber Edom als auch im Auftreten von speziellen Schlüsselwörtern und verbalen Resonanzen gesehen werden. Darüber hinaus deutet die Kontinuität in der Darstellung von Edom in 4. Mose und in den Propheten auf eine zugehörige Diskontinuität mit der Schilderung dieser Themen in anderen Traditionen hin, vor allem in 1. und 5. Mose. 
Les deux références à Edom dans le livre des Nombres (20,14-21 et 24,18-19) ont souvent été détachées l'une de l'autre et donc traitées individuellement. Cet article suggère une continuité entre elles qui peut être trouvée dans le fait que, prises ensembles, ces références offrent une image plus claire de la représentation habituelle d'Edom par la suite dans la littérature prophétique. Les similarités entre le livre des Nombres et les prophètes peuvent être entrevues comme une disposition négative envers Edom tout comme dans les occurrences de mots clés spécifiques et de résonances verbales. De plus, la continuité entre la représentation d'Edom dans Nombres et dans les prophètes suggère une discontinuité correspondante dans la représentation de ces thèmes dans d'autres traditions, dans la Genèse et le Deutéronome notamment, qui sont beaucoup plus positifs dans leur portrait d'Esaü et d'Edom.

\section{Introduction}

Making sense of the references to Edom in the book of Numbers is no small task, for a number of reasons. ${ }^{1}$ To begin with, the Israelite journey along the Transjordan that leads to an encounter with the Edomites in Num 20,14-21 is also depicted in Deut 2, with differing outcomes and notably dissimilar points of view. Not surprisingly, this has led to numerous studies on the sources, dating, and literary dependence of these texts, ${ }^{2}$ not to mention attempts at harmonisation. ${ }^{3}$ Secondly, the subsequent reference to

\footnotetext{
${ }^{1}$ Standard introductions to the study of Edom include F. Buhl, Geschichte der Edomiter, 1893; J.R. Bartlett, Edom and the Edomites, JSOTSup 77, 1989; and the collection of essays in D.V. Edelman (ed.), »You Shall Not Abhor an Edomite for He is Your Brother«: Edom and Seir in History and Tradition, ABS 3, 1995.

${ }^{2}$ Helpful summaries and discussions on the issues related to these texts and traditions can be found in the major commentaries, including M. Noth, Numeri, ATD 7, 1966, 130-133; H. Seebass, Numeri 2, BKAT IV/2,4, 2003, 287-297; J. de Vaulx, Les Nombres, 1972, 226-230; J. Milgrom, Numbers, JPSTC, 1990, 167-169.463-467; B.A. Levine, Numbers 1-20, AB 4a, 1993, 491-494; E. Nielsen, Deuteronomium, HAT I/6, 1995, 32-38; H.D. Preuss, Deuteronomium, EdF 164, 1982, 75-80; J.H. Tigay,
} 
Edom in Numbers occurs at Num 24,18-19 within the oracles of Balaam, a section of the book with its own myriad difficulties. ${ }^{4}$ These two issues lead to a third factor,

Deuteronomy, JPSTC, 1996, 422-429; and M. Weinfeld, Deuteronomy 1-11, AB 5, 1991, 165f. More specific studies on these themes include W.A. Sumner, Israel's Encounters with Edom, Moab, Ammon, Sihon, and Og According to the Deuteronomist, VT 18 (1968), 216-228; J.T. Walsh, From Egypt to Moab: A Source Critical Analysis of the Wilderness Itinerary, CBQ 39 (1977), 20-33; G.I. Davies, The Wilderness Itineraries and the Composition of the Pentateuch, VT 33 (1983), 1-13; G.W. Coats The Wilderness Itinerary, CBQ 34 (1972), 135-152; D.A. Glatt-Gilad, The Re-Interpretation of the Edomite-Israelite Encounter in Deuteronomy II, VT 47 (1997), 441-455; J. van Seters, The Conquest of Sihon's Kingdom: A Literary Examination, JBL 91 (1972), 182-197; J.R.Bartlett, The Conquest of Sihon's Kingdom: A Literary Re-Examination, JBL 97 (1978), 347-351.

${ }^{3}$ Although attempts have been made to harmonise the two depictions, or to suggest two separate encounters, these have been, on the whole, less than persuasive. Pre-modern attempts at such readings can be found in Rashi, Ramban and John Calvin, among others. See M. Rosenbaum and A.M. Silbermann, Pentateuch with Targum Onkelos, Haphtaroth and Rashi's Commentary, vol. 5, 1934, 16; Ramban: Commentary on the Torah, vol. 5, trans. C.B. Chavel, 1976, 280-282. J. Calvin, Commentaries on the Four Last Books of Moses, trans. C.W. Bingham, 1855, 138-143; For an extensive treatment of the history of interpretation of these episodes, notably the Deuteronomic version, see J. Maier, Israel und Edom in den Ausdeutungen zu Dtn 2:1-8, in: C. Thoma (ed.), Judentum - Ausblicke und Einsichten (Festschrift Schubert), 1993, 135-184.

${ }^{4}$ On Balaam and Num 22-24, along with the commentaries noted above, see H. Rouillard, La péricope de Balaam (Nombres 22-24): la prose et les oracles, 1985; M.S. Moore, The Balaam Traditions: Their Character and Development, SBLDS 113, 1990; J.T. Greene, Balaam and His Interpreters: A Hermeneutical History of the Balaam Traditions, BJS 244, 1992; Rainer Bickert, Israel im Lande Moab. Die Stellung der Bileamerzählung Num 22-24 in ihrem redaktionellen Kontext, ZAW 121, 2009, 189-210; M. Rösel, Wie einer vom Propheten zum Verführer wurde: Tradition und Rezeption der Bileamgestalt, Bib 80 (1999), 506-524; H. Seebass, Zur 
which is that the two references to Edom within Numbers are rarely discussed in relationship to one another, most often because of perceived differences in settings and origins.

Nevertheless, there are important points of contact between these texts concerning Edom, issues that have largely been ignored in scholarship. I would like to suggest that the references to Edom in Num 20,14-21 and 24,18-19 are related insofar as they both contain several areas of overlap with how Edom is portrayed elsewhere in the Hebrew Bible, in particular the prophetic literature. ${ }^{5}$ The similarities between Numbers and the prophets can be seen both in terms of the general disposition towards Edom as well as the occurrence of specific key words and verbal resonances. ${ }^{6}$ This resonance with the prophetic literature suggests a concomitant discontinuity with the portrayal of these

literarischen Gestalt der Bileam-Perikope, ZAW 107 (1995), 409-419; and more specifically on the text in question, K. Seybold, Das Herrscherbild des Bileamorakels Num. 24,15-19, TZ 29 (1973), 1-19.

${ }^{5}$ It has been noted on occasion that elements of the portrayal of Edom in Numbers have resonance with what the prophetic literature has to say concerning Israel's neighbor. The thoroughgoingness of these resonances, however, has not fully been explored. See, e.g., most notably Rouillard (La péricope de Balaam, 470-474); see also de Vaulx, Les Nombres, 229.290; and P.R. Raabe, Obadiah, AB 24D, 1996, 248-249.

${ }^{6}$ On the prophetic hostility toward Edom, see E. Assis, Why Edom? On the Hostility Towards Jacob's Brother in Prophetic Sources, VT 56 (2006), 1-20; B. Dicou, Edom, Israel's Brother and Antagonist: The Role of Edom in Biblical Prophecy and Story, JSOTSup 169, 1994; B.C. Cresson, The Condemnation of Edom in Post-Exilic Judaism, in: J.M. Efird (ed.), The Use of the Old Testament in the New and Other Essays: Studies in Honour of William Franklin Stinespring, 1972, 125-148; B. GlazierMcDonald, Edom in the Prophetical Corpus, in D.V. Edelman (ed.), »You Shall Not Abhor an Edomite for He is Your Brother«: Edom and Seir in History and Tradition, ABS 3, 1995, 23-32. 
same subjects and motifs in other aspects of the Hebrew Bible, notably Genesis and Deuteronomy. ${ }^{7}$

Although there are numerous historical, source-critical, and theological issues which present themselves in light of this study, in the present work I will focus on literary aspects of the portrayal of Edom in Numbers, giving special attention to continuity and discontinuity with other texts and traditions of the Hebrew Bible.

\section{Edom in Numbers 20,14-21}

Edom first appears in Numbers as the Israelites are about to make their way through the Transjordan towards Canaan, immediately following the incident at Meribah (Num 20,1-13), and directly preceding the death of Aaron (20,22-29). Here the Israelites wish to pass through Edom so as to shorten their journey to Canaan (20,14-17). However, Edom rejects Israel's request (20,18-21), and Moses is forced to lead the people on an indirect route circumventing Edom $(21,4) .{ }^{8}$ Two issues stand out in this depiction of Edom, particularly in light of the prophetic literature. First is the use of kinship terminology, and second is the overall negative disposition toward Edom and the use of key words that occur in both traditions that contribute to this negative portrayal.

\footnotetext{
${ }^{7}$ For more on Esau and Edom in Genesis and Deuteronomy and the relation of these to the prophetic literature, see B.A. Anderson, Brotherhood and Inheritance: A Canonical Reading of the Esau and Edom Traditions, LHBOTS, forthcoming.

${ }^{8}$ On issues of textual geography in this narrative, see J.M. Miller, The Israelite Journey Through (Around) Moab and Moabite Toponymy, JBL 108 (1989), 577-595; and H. Seebass, Edom und Seine Umgehung nach Numeri XX-XXI: zu Numeri XXI 10-13, VT 47 (1997), 255-262.
} 


\subsection{Edom as Kin}

One might first note that Numbers stands in line with both the pentateuchal and prophetic traditions in referring to Israel and Edom as kin. The encounter begins in Num 20,14 with Moses sending messengers to the king of Edom with a message that

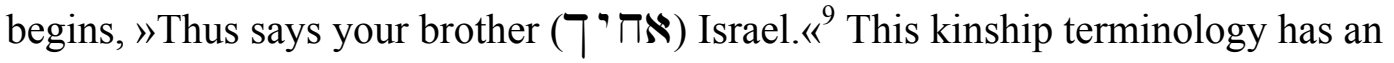
obvious rhetorical purpose in Moses' message, highlighting the special relationship between the two peoples so as to gain favour and thus access to Edom's land.

The fact that Numbers designates Edom as kin should not be surprising, as the kinship motif between Jacob/Israel and Esau/Edom is well represented elsewhere in the Pentateuch, both in Gen 25-36 and in Deut 2,4 and 23,8. ${ }^{10}$ One might take for granted that all of these traditions simply highlight the strife implicit in the relationship of the eponymous ancestors and their descendants, especially if focus is placed on the initial hostility between Jacob and Esau in Gen 25 and 27. However, the depiction of Esau and Edom is not entirely negative, particularly the latter parts of the Jacob Cycle; indeed, one could argue that with the reconciliation of Jacob and Esau in Gen 32-33, the burial of their father in Gen 35,29, and the large amount of space devoted to Esau's descendants in Gen 36, Jacob's brother plays a central and quite positive role in the cycle of stories. Moreover, the somewhat surprising positive portrayal of the sons of Esau and Edom in Deuteronomy adds to this, and might lead one to conclude that the theme of Edom's kinship in Genesis and Deuteronomy is more positive than is often assumed. ${ }^{11}$ In this sense, the portrayal of Edom's kinship in Numbers stands in contrast with how this motif plays out in the other pentateuchal traditions.

\footnotetext{
${ }^{9}$ All translations are my own.

${ }^{10}$ On historical and source-critical issues related the development of this brotherhood motif with regard to Jacob/Israel and Esau/Edom, see J.R. Bartlett, The Brotherhood of Edom, JSOT 4 (1977), 2-27.

${ }^{11}$ On the need to rethink the portrayal of Esau in Genesis, see R.C. Heard, Dynamics of Diselection: Ambiguity in Genesis 12-36 and Ethnic Boundaries in Post-Exilic Judah, SLBDS 39, 2001, 97-137; and F.A. Spina, The »Face of God«: Esau in Canonical
} 
A further way of looking at this issue, however, is to compare the use of the IsraelEdom kinship motif in Numbers with its use in the prophetic corpus. The use of kinship terminology to describe Edom recurs in Obadiah and Amos, and here the focus is on Edom's unbrotherly behaviour. ${ }^{12}$ The kinship language in Obadiah is concentrated in vv. 10-12, which refer to the violence done to brother Jacob (מחמם אח יד י עקב) and

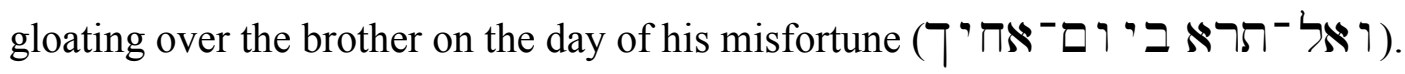
These reprimands seem to be rooted in the accusation of $\mathrm{Ob} 11$ : »On the day that you stood aside, on the day that strangers carried off his wealth, and foreigners entered his gates and cast lots for Jerusalem, you too were like one of them

א.(גם Thus, it is the issue of kinship that implies Edom should have acted differently from the other nations, and is the basis for the prophet's contempt for his neighbour. ${ }^{13}$

Context, in: C.A. Evans and S. Talmon (eds.), The Quest for Context and Meaning: Studies in Biblical Intertextuality in Honor of James A. Sanders, 1997, 3-25. For similar sentiments with regard to Deuteronomy, see P.D. Miller, The Wilderness Journey in Deuteronomy: Style, Structure, and Theology in Deuteronomy 1-3, in: Israelite Religion and Biblical Theology: Collected Essays, JSOTSup 267, 2000, $572-$ 592; and O. Bächli, Israel und die Völker: Eine Studie zum Deuteronomium, ATANT 41, 1962, 121-122.

${ }^{12}$ Mal 1,2-5 also makes mention of the brotherhood of Jacob and Esau, but in this context it seems to serve a different purpose, highlighting the election of Jacob over Esau, and thus reminding post-exilic Israel of YHWH's love for them. For more on this, see Anderson, Brotherhood and Inheritance.

${ }^{13}$ The importance of this kinship motif has of course been pointed out elsewhere. See, for example, J. Jeremias, Die Propheten Joel, Obadja, Jona, Micha, ATD 24,3, 2007, 59; H.W. Wolff, Obadiah and Jonah, trans. M. Kohl, 1986, 52-53; W. Rudolph, Joel, Amos, Obadja, Jona, KAT 13,2, 1971, 309; E. Ben Zvi, A Historical-Critical Study of the Book of Obadiah, BZAW 242, 1996, 238-46; J. Barton, Joel and Obadiah, OTL, 2001, 128. 
This kinship terminology recurs in Amos, in the context of Amos's oracles against the nations. ${ }^{14}$ In Am 1,6 and 1,9, Gaza and Tyre are castigated for selling communities of captives to Edom. In v. 9 this is said to disregard brotherhood.« The oracle against Edom commences in 1,11, where we read: »Thus says YHWH: for three transgressions of Edom, and for four, I will not relent. Because he pursued his brother with the sword (י י איל-רדפו בחרבי), and cast off all compassion. «It is clear that a special relationship was deemed to have been violated by Edom's actions, and this lies behind Amos's strong denunciation of Edom, which again is noted as kin. ${ }^{15}$

Returning to Num 20,14-21, it would seem that the representation of Edom as kin in Numbers has more in common with the prophetic castigation of Edom than it does with the use of the motif elsewhere in the Pentateuch. Though Israel appeals to its status as kin, Edom strongly rebuffs their attempted approach, and thus acts in an inhospitable, perhaps unfamilial, manner.

\subsection{Key Words in Numbers 20,14-21 and the Prophets}

This depiction of Edom as acting in a manner unbecoming of kin in Num 20,14-21 has further resonance with the prophetic books, notably in key words that occur in both traditions.

\footnotetext{
${ }^{14}$ On the general context, see J. Barton, Amos's Oracles against the Nations: A Study of Amos 1.3-2.5, SOTSMS 6, 1980.

${ }^{15}$ There are a number of ways this kinship motif has been construed with regard to the prophetic literature. It may well be, as Fishbane and others have noted, that the kinship language has a broader frame of reference than simply a shared history, but may refer to treaties or other political relationships. See M. Fishbane, The Treaty Background of Amos 1:11 and Related Matters, JBL 89 (1970), 313-318. Whatever the case, the sense remains clear: according to Obadiah and Amos, Edom has violated some sort of special relationship, a relationship that can be classified under the rubric of kin.
} 
To begin with, in Num 20,18 the king of Edom warns that if Israel tries to pass through the land, Edom will come out to meet them with the sword

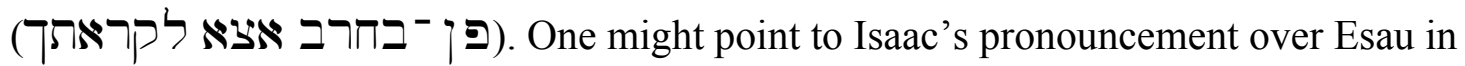
Gen 27,39-40, with its declaration that Esau will live by the sword (ו על יחרבך תחי ה), as a possible point of reference for this statement from the king of Edom. In fact, the use of the root קר in Num 20,18 also brings to mind the reconciliation episode in Gen 32-33, where an anxious Jacob is told his brother is coming to meet him (לקראזך; 32,7), as well as the moment of truth when Esau runs to meet Jacob (ו י ריץ עשו לקראו before embracing him, kissing him, and weeping with him, in true brotherly fashion $(33,4)$. In this sense, Esau does not respond violently to the brother who has wronged him, but instead embraces him and welcomes him home. ${ }^{16}$ When read in this light, the use of the terms קר מר and and 20,18 may be pushing back against the positive portrayal of Esau and Edom in Genesis, which would again point to the discontinuity between these texts and traditions, while reinforcing the resemblance between Numbers and the prophetic texts concerning Edom. In point of fact, similarities are once more found in the prophets, notably Am 1,11, which, as noted above, chastises Edom for pursuing their kin with the sword

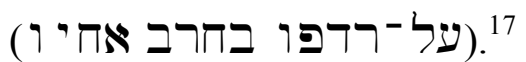

Two further resonances with the prophets are found in Num 20,21. First, we are told that Edom refuses to give passage to Israel through their territory ( בצל וב). The use of the term \בו is also reminiscent of the prophetic tradition concerning Edom. While Numbers here notes Edom's refusal to grant passage through their territory, $\mathrm{Ob} 7$

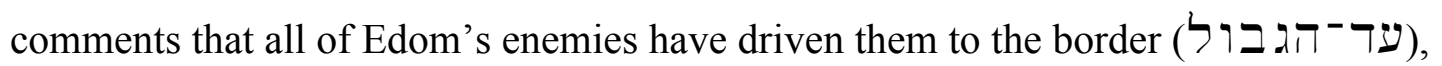

\footnotetext{
${ }^{16}$ For more on this episode, see K. Schmid, Die Versöhnung zwischen Jakob und Esau (Gen. 33,1-11), in: J.-D. Macchi and T. Römer (eds.), Jacob: Commentaire à plusieurs voix de Gen 25-36; Mélanges offerts à Albert DE PURY, MdB 44, 2001, 211-226.

${ }^{17}$ Levine, Numbers 1-20, 493.
} 
and Mal 1,4 recounts YHWH's threat to perpetually frustrate Edom until they are called»the wicked territory«(גבוּ רשעה). Both of these prophetic utterances speak to Edom receiving its comeuppance (in this case regarding its border or territory, フ ג) in light of Edom's behaviour toward their kin. The specific terminology used in these texts is reminiscent of the unbrotherly way in which Numbers refers to Edom's protection of its territory ( 1 בג, Num 20,21).

Secondly, after this refusal of passage by Edom in Num 20,21, the text notes that

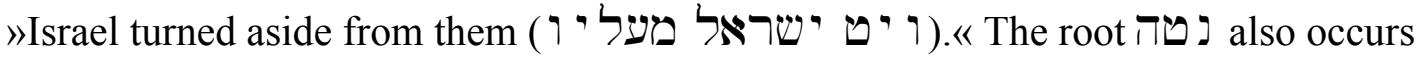
several verses earlier in Israel's request for passage $(20,17)$, where the Israelites promised to not turn aside (נטה) to the right or the left on their way through Edom. This same root is found in another prophetic critique of Edom, Ez 35,3, where it reads, »I am against you, Mt. Seir, and I will stretch out (" I will make you a desolation and wasteland.« Thus, as Israel was forced to »turn aside« ( $\left.\bullet^{\bullet}\right\urcorner$, Num 20,21) from Edom because Edom would not show hospitality, so YHWH will »stretch out« ("תי ', Ez 35,3) his hand against Mt. Seir (Edom) and destroy it.

Taken together, there are a variety of references in Num 20,14-21 that depict Edom in ways that are suggestive of the prophets, including the kinship motif (ח\$) and key

terms and phrases such as »sword«(חר), »territory«(クル ג), and »turn aside/stretch out«(נפה). Such resonances also reinforce the contrast with regard to how Numbers and Genesis/Deuteronomy speak of Edom.

\section{Edom in Numbers 24,18-19}

The second reference to Edom in Numbers $(24,18-19)$ occurs in the midst of Balaam's final blessing of Israel, in the larger collection of narratives concerning Balaam. Again, 
these verses exhibit several key words that are used in conjunction with Edom in the prophetic books, a number of which I shall here highlight. ${ }^{18}$

\subsection{Edom and the Land}

To begin with, Num 24,18 reads, »And Edom will become a possession (רשה ); and

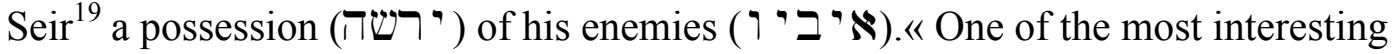
aspects of this verse is the dual usage of the term רשה ", " "possession. ${ }^{20}$ Like the term ח described above, the root ${ }^{י}$ occurs in both the pentateuchal and prophetic depictions of Edom.

In Deuteronomy, as the Israelites are about to pass through Seir in the final stages of their journey toward Canaan, we read the following in Deut 2,4-5: »You are about to pass through the territory of your kin (פי Seir. They will be afraid of you, so be careful not to engage in battle with them, for I

${ }^{18}$ As noted above, a number of these resonances have been highlighted by Rouillard (La péricope de Balaam, 470-471), though the excursus is limited to those similarities found in Obadiah. A. Marx has noted the relationship of this passage with the oracles of Gen 27 , and sees this as an attempt to negate any positive elements that might be inferred from these, instead bringing to the fore Jacob/Israel's dominance. See A. Marx, A Propos de Nombres XXIV 19b, VT 37 (1987), 100-103. As such, Marx’s thesis matches up well with the argument I am here putting forward, which posits discontinuity between Numbers and the other pentaeuchal traditions which speak of Edom.

${ }^{19}$ The LXX here amends Seir to Esau, which points to the fluidity these various designations (Edom, Seir, Esau) came to have over time. On possible historical reconstructions concerning the connection of Edom and Seir, consult J.R. Bartlett, The Land of Seir and the Brotherhood of Edom, JTS 20 (1969), 1-20.

${ }^{20}$ For more on this term, see N. Lohfink, רששי, TDOT, 6:368-396. 
will not give you even so much as a foot's length of their land, since I have given Mount Seir to Esau as a possession (ירשה ).«The idea that Canaan is a gift from YHWH to be possessed or inherited by Israel is found frequently in Deuteronomy,

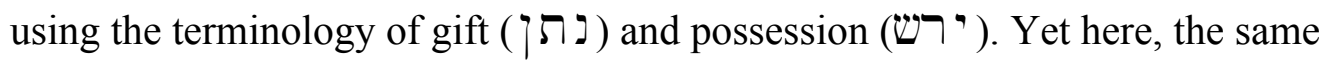
language is used with regard to the sons of Esau (as well as Moab and Ammon later in the chapter), to describe the land of their dwelling. Israel's God has given the land of Seir to the descendants of Esau as a possession in the same manner which Canaan is to be given to Israel. Indeed, later in Deut 2,22, it is made clear that YHWH helped Esau's progeny dispossess (ירשה) those who were in the land before them. Taken together, Deut 2 give the impression that Esau's descendants have been given the land of Seir as a possession or inheritance, no small claim. ${ }^{21}$

In the prophetic oracles concerning Edom, one also finds the language of possession, dispossession, and inheritance. Here, however, the tables are turned, and Edom is dispossessed. A few examples will suffice.

In the oracle concerning Edom in Isa 34 and extending into ch. 35, judgment is pronounced upon Edom. ${ }^{22}$ In 34,5 we read, »For my sword has drunk its fill in the heavens. Behold, upon Edom it will descend, and upon the people I have devoted to the ban for judgment.« The following verses expand on this judgment with stark imagery of Edom's slaughter. First, animal imagery is used, evoking a picture of sacrifice (vv. 6-7), and this is followed by a depiction of the land, which becomes desolate and uninhabitable (vv. 9-15). It is in these verses that we encounter the familiar language of possession. In 34,11a it states concerning Edom, » The hawk and the hedgehog will

${ }^{21}$ Note also Jos 24,4, which reinforces the sentiments found in Deuteronomy: »to Isaac I gave Jacob and Esau. I gave Esau the hill country of Seir to possess (לרשת), but Jacob and his children went down to Egypt.«

${ }^{22}$ On these chapters, see C.R. Matthews, Defending Zion: Edom's Desolation and Jacob's Restoration (Isaiah 34-35) in Context, BZAW 236, 1995; B. Gosse, Isaïe $34-$ 35: Le châtiment d'Edom et des nations, salut pour Sion, ZAW 102 (1990), 396-404. 


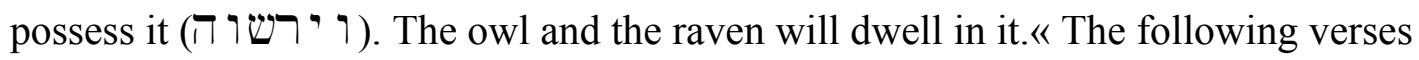
make it clear that the only inhabitants of Edom will be the wild animals. The chapter closes with a reminder that YHWH ordains these happenings $(34,17)$ : $\gg \mathrm{He}$ casts lots for them, and his hand divides them with the line. In perpetuity they will possess it (רשו"י ), and from generation to generation they will dwell in it."We see here the motif of Edom's land becoming desolate and dispossessed - this time by desert animals, as decreed by $\mathrm{YHWH}^{23}$

Moving to Ez 35-36, Ezekiel's main oracle concerning Edom and subsequent salvation oracle, we find that these chapters are again rife with references to land possession and inheritance. ${ }^{24}$ In 35,10 the reason for Edom's desolation is given: »Because you have said, These two nations and two lands, they will be mine, and we will possess them

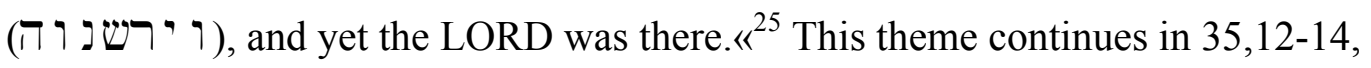
where it is made clear that Edom took advantage of Judah in a time of calamity, and this was taken as an offense against YHWH. Ezekiel 35,15 continues, »As you rejoiced over the inheritance (ל נחדל) of the house of Israel when it was desolate, thus I will do to you.«

${ }^{23}$ Elsewhere Isaiah uses the root רשש almost exclusively with reference to Israel's relationship to the land of promise - the land is to be Israel's possession; See, e.g., Isa 57,$13 ; 60,21 ; 61,7 ; 63,18 ; 65,9$. One exception is this reference to Edom's dispossession; the other exceptions are 14,21, which speaks of evildoers not possessing the earth, and 14,23, which uses the nominal form (פורשוש), where once again it is the hedgehog that possesses Babylon.

${ }^{24}$ On Edom in Ezekiel, consult M.H. Woudstra, Edom and Israel in Ezekiel, CTJ 3 (1968), 21-35; and H. Simian, Die theologische Nachgeschichte der Prophetie Ezechiels: Form- und traditionskritische Untersuchung zu Ez 6; 35; 36, FzB, 1974. ${ }^{25}$ The two nations here most likely refer to Israel and Judah. See M. Greenberg, Ezekiel 21-37, AB 22a, 1997, 715; W. Zimmerli, Ezekiel 2, Hermenia, trans. J.D. Martin, 1983, 235. 
The theme of inheritance and possession continues into the salvation-oriented oracle of Ez 36. In 36,2-3 we read, »Thus says the Lord YHWH: Because the enemy said concerning you, Aha! The ancient high places have become a possession (למו רשה) for us. Therefore prophesy and say, Thus says the Lord God: Because they desolated and crushed you from all sides so that you became a possession (מורשה) for the rest of the nations... « This idea is picked up again in v. $5 \mathrm{~b}$, with specific reference to the nations, and particularly Edom, who »wholeheartedly gave my land to themselves for a possession (למורשה). In 36,12, YHWH speaks to the mountains and the land itself, stating: »I will cause people, my people Israel, to walk upon you; and they will possess you (ו י ירשו ) and you will be for them an inheritance (ל נחלד). Once again, a reversal of fortune is in mind, as 35,15 makes clear: as Edom rejoiced over Israel's inheritance, so the same will be done to them. ${ }^{26}$

The use of the kinship motif in Amos was noted earlier. Amos makes another reference to Edom in ch. 9, but here it is the land and possession motif which takes precedence. Am 9,11-12 reads: »On that day I will raise up the fallen booth of David. And I will repair its breaches, and its ruins I will raise up, and build it as in the days of antiquity; in order that they may possess (רשו" ) the remnant of Edom and all the nations which are called by my name, declares YHWH, the one who does this.« Once again the

${ }^{26}$ Ezekiel uses two roots, רש יר and, concerning Israel's relationship to her land, and how the Edomites view it. Though not identical, they are used in parallel here, and seem to have similar functions in the text. Malachi also makes use of the land motif in the depiction of Edom by using the term נחלדה. In Mal 1,3-4 we read, »I have hated

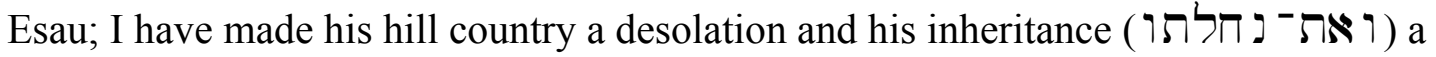
desert for jackals.« Again, we here encounter inheritance-related terminology in relation to the destruction of Edom, though this time the author speaks of the desolation

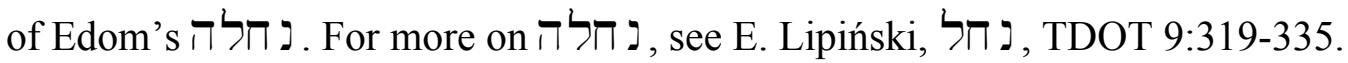


leitwort ירש is used in relation to Edom. While Edom's remnant is dispossessed, Israel reclaims the land of promise. $^{27}$

In Obadiah, we again find the repeated use of the root רשי ${ }^{\cdot 28}$ In v. 17 we read, »But on Mount Zion there will be escape, and it will be holy. And the house of Jacob will

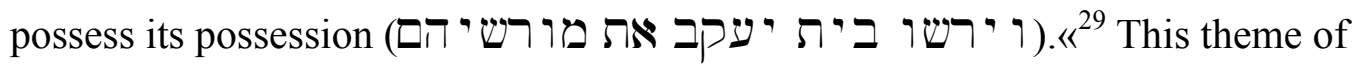
»possessing « is picked up again in vv. 19-21, which begin: »And the Negeb will possess (ו ירשו Mount Esau.« Here it is the region closest to Edom, the Negeb, which is to possess the territory of Esau's descendants. ${ }^{30}$ Taken together, these two references ( $\mathrm{Ob} 17$ and 19) make clear that the people Israel will repossess Judah, and Edom will be dispossessed from her land (and possibly displaced from Judah).

Taken in sum, there is a strong recurring usage of the root ${ }^{\prime}$ and possession-related language in Deuteronomy as well as the prophetic depiction of Edom. This same

${ }^{27}$ It should be noted that the variant reading of Amos 9,12 in the LXX is a substantial difference, as both »Edom« and »possession« are missing in the Greek, which instead speaks of a »remnant of mankind. « This may reflect the fact that Obadiah follows Joel and not Amos in the LXX ordering of the Twelve. See B.A. Jones, The Formation of the Book of the Twelve: A Study in Text and Canon, SBLDS 149, 1995, 175-177. Note, however, that the Targum to the Prophets retains the reference to Edom. ${ }^{28}$ More on this theme can be found in B.A. Anderson, Poetic Justice in Obadiah, JSOT 35 (2010), 247-255.

${ }^{29}$ There are textual difficulties here, particularly on the pointing of ממו רשי יהם; for more on this, see Anderson, Poetic Justice in Obadiah, 250-251.

${ }^{30}$ It is natural to assume that Edomitic incursions into Judah would have been in the Negeb. This might explain why the Negeb is singled out as the possessor of Edom: those who took possession of the Negeb will have the same done to them. As GlazierMcDonald comments, the stransformation of Edom from an enemy to the enemy is clearly attributed to Edom's movement from its own land to southern Judah, which is Yahweh’s land« (Glazier-McDonald, Edom in the Prophetical Corpus, 31). 
language, as we have seen, recurs in Num 24,18. The usage in Numbers is obviously negative, as it speaks of Edom becoming a »possession«, the opposite of what is laid out in Deut 2,4. As such, the use of this term in Numbers seems again to find resonance in the prophetic depiction of Edom, which speaks repeatedly of Edom's dispossession.

\subsection{Israel's Enemy, Edom's Enemies}

A further verbal resonance with the prophetic literature is found in Num 24,18. This verse notes that Seir will become a possession (רשה ) of its enemies (

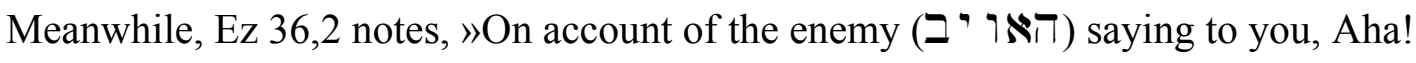
The ancient heights are a possession for us (לפו רשה)... While the text does not state who the enemy is in this instance, it is reasonably clear, based on chapter 35 and the recurring usage of the root רשי", that Edom is in mind. Thus, both Numbers and Ezekiel use the terminology of »possession« and »enemy« in conjunction with Edom. While Ez 36,2 states that Edom, as the enemy, saw Israel's land as its possession, Num 24,18 declares that Edom will become a possession of its enemies.

\subsection{Israel's Wealth/Strength}

Numbers 24,18 concludes by noting that, in juxtaposition to Edom's dispossession, »Israel will do valiantly $(\zeta \cdot$ ).«This term concerning Israel's future strength is also used in Obadiah, where it is used in a different manner. In Ob 11 we read, »On the day you stood aside, on the day strangers took captive his wealth (חיל entered his gates, and cast lots for Jerusalem, you also were as one of them.« Two verses later, $\mathrm{Ob} 13 \mathrm{~d}$ reads, »You should not have taken his wealth (イל of his destruction. « Thus, in Obadiah Edom is reprimanded for taking part (or allowing to take place) the sacking of Jerusalem, and the wealth (ולי) therein. This action will result in the downfall of Edom. Meanwhile, Num 24,18 makes clear that while 
Edom is destroyed, Israel's strength (חיל) will be restored. ${ }^{31}$ Indeed, this resonance is highlighted in Targum Onqelos, which amends the end of Num 24,18 to read that

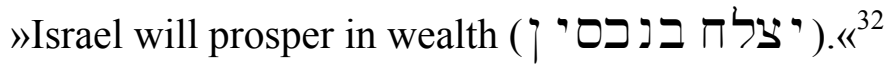

\subsection{Destruction of Edom's Survivors}

Finally, we come to Num 24,19, the second verse of Balaam's pronouncement concerning Edom, where we find two further resonances with the prophetic depiction of Edom. ${ }^{33}$ The verse begins by noting, »One from Jacob ${ }^{34}$ will rule, and destroy

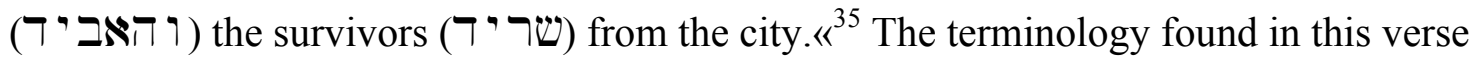

${ }^{31}$ Rouillard, La péricope de Balaam, 470.

${ }^{32}$ Most likely following Deut 8,17-18. See the comments in B. Grossfeld, The Targum Onqelos to Leviticus and Numbers, ArBib 8, 1987, 138-139.

${ }^{33}$ There is some debate as to whether or not Num 24,18 and 19 should be considered as related, or if v. 18 is simply an interpolation. On these issues, see Levine, Number 2136, 203-204. Based on the resonances pointed out in what follows, as well as the numerous connections made in the history of interpretation, understanding v. 19 as continuing the oracle against Edom would seem to be a valid reading. However, it should be noted that 1QM 11.7 omits both Edom and Seir, referring instead simply to "the enemy."

${ }^{34}$ Interestingly, Targum Onqelos adds »house of « to Jacob in Num 24,19, an insertion that adds further resonance to Obadiah, which uses the same appellation in Ob 18-19. ${ }^{35}$ It is unclear whether the term מע י ר a a the end of Num 24,19 should be read as a noun or a proper name: is this a reference to a general city, or a place called Ar/Ir? See the discussion in H. Seebass, Numeri 3, BKAT IV/3,1, 2007, 25; B.A. Levine, Numbers 21-36, AB 4a, 2000, 203-204. Targum Onqelos clarifies this by rendering it as »from the city of the nations«, upon which Rashi adds a further gloss: »the most important city of Edom-Rome.« See Grossfeld, The Targum Onqelos to Numbers, 138-139. The LXX offers another clarification, speaking of destruction for »one from the city that escapes.« This allusion to one who »escapes« offers another interesting 
is especially reminiscent of Obadiah, where similar language is used. In Ob 14 we read, »You should not have stood at the crossings to cut off his fugitives; you should not

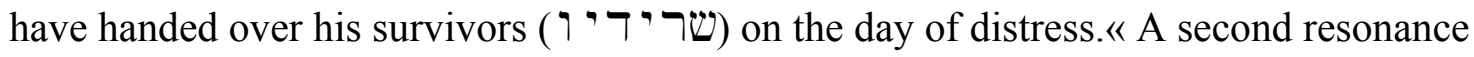
occurs in Ob 18b, which states, »there shall be no survivor (שרי ד) of the house of Esau; for YHWH has spoken.« Thus, as Edom handed over those »survivors« from Judah's day of calamity (Ob 14), so Edom itself will have no »survivors« (Ob 18). Taken together, both Numbers and Obadiah use the same terminology in referring to survivors (שר י ד), and both also speak of their ruination. ${ }^{36}$

The second issue to grab the reader's attention in Num 24,19 is the use of the root דבא, »destroy.« This term is also used prominently in Obadiah's diatribe against

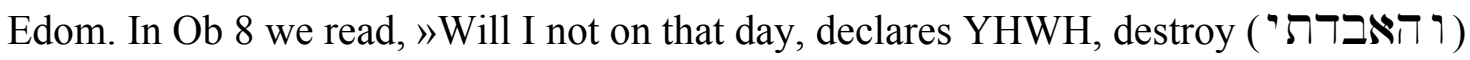
the wise ones from Edom, and understanding from Mount Esau? « A few verses later, in v. 12b, it states, »You should not have rejoiced over the sons of Judah on the day of

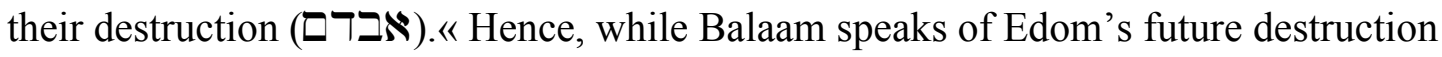

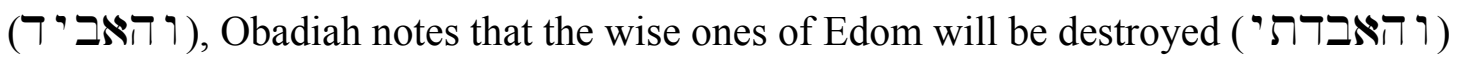
by YHWH because they rejoiced over Judah's destruction (םדבא).

To review, the second occurrence of Edom in Numbers again has much in common with the prophetic portrayal of Israel's neighbour, and once more adds distance between Numbers and Deuteronomy. This can be seen in the land motif and the use of the root רשש", as well as in the use of other key words and ideas such as »enemies« (ב`ふ), »wealth/strength«(

connection to Obadiah, where similar escape-related terminology can be found in $\mathrm{Ob}$ 14.17a. On this, see Anderson, Poetic Justice in Obadiah, 249-250.

${ }^{36}$ This connection was noted in antiquity by, amongst others, Rashbam (Rashbam's Commentary on Leviticus and Numbers: An Annotated Translation, trans. M.I. Lockshin, BJS 330, 2001, 281). Cf. Rouillard, La péricope de Balaam, 470; Raabe, Obadiah, 248-249; Milgrom, Numbers, 208. 


\section{Conclusion}

This study has explored the portrayal of Edom in the book of Numbers, suggesting that the two texts in Numbers that make reference to Israel's neighbour have considerable continuity with the prophetic portrayal of Edom. This resonance can be seen in the similarly negative dispositions of these traditions concerning Edom, as well as in specific key words and phrases which can be found in both Numbers and the prophetic corpus. As such, these two Edom-related texts in Numbers may have more in common than is generally assumed, sharing both the vitriol and the vocabulary common in the prophetic castigation of Edom. This resonance which Numbers has with the prophets, it was pointed out, also suggests a corresponding dissimilarity with how both Esau and Edom are portrayed elsewhere in the Pentateuch, notably Genesis and Deuteronomy, where issues such as kinship (\$) and land possession ("רשי) are construed in a much more positive fashion. In light of these findings, the discerning reader of the Hebrew Bible might wonder if perhaps the book of Numbers would feel more at home among the prophets rather than the Pentateuch, at least in matters concerning Israel's neighbour and kin, Edom. 